\title{
METSZŐKERÉKKEL LEFEJTETT FOGASKEREKEK PROFILPONTOSSÁGÁNAK VIZSGÁLATA
}

\section{THE ANALYSIS OF THE TOOTH PROFILE PRECISION BY GEARS MESHED USING SHAPER CUTTER}

\author{
Máté Márton ${ }^{1}$, Kántor Anna Erzsébet ${ }^{2}$, Laczkó Benedek Brigitta ${ }^{3}$ \\ Sapientia-Erdélyi Magyar Tudományegyetem, Marosvásárhelyi Kar, Gépészmérnö- \\ ki Tanszék, 540485 Marosvásárhely, O.p.9, C.P 4, Telefon / Fax: +40-265-206210 / \\ +40-265-206211, \\ Immate@ms.sapientia.ro
}

\begin{abstract}
As well is known, tooth profiles of gears manufactured with use of classical shaper cutters differ from the theoretical involute curve. The error is accepted because it is considered that it reduces the top land and dedendum tooth thickness. The present paper shows that the repartition of the errors on the tooth profile can result in many different modes, only a few fulfilling the hypothesis stated above. This paper presents the mathematical model of the meshing between the right teethed gear shaper cutter and the gear. The exact profile equations of the gear tooth are computed. After this, the error is defined as the normal distance between the theoretical involute and the real tooth profile. The error is considered positive when it is situated in the tooth. Finally it is demonstrated, that the repartition of the errors depends on the number of teeth and the profile shifting coefficients.
\end{abstract}

Keywords: shaper cutter, gear, tooth profile, error, tooth number, profile shifting, distribution

\section{Összefoglalás}

Jól ismert tény, hogy a metszőkerékkel fogazott fogaskeréknek profilhibája van. A szakirodalomban általánosan elfogadott vélemény, hogy e hiba a fogfej- és a foglábvastagságot csökkenti, így a kapcsolódás szempontjából előnyös. Jelen dolgozatban kimutatjuk, hogy ez a feltételezés csak bizonyos esetekben igaz. Tárgyaljuk a metszőkerekes burkolás matematikai modelljét és ennek alapján felírjuk a burkoló fogoldal profiljának parametrikus egyenleteit. A következőkben a profilhibát definiáljuk. A profilhiba pozitív, ha a fog belseje felé irányított. Végül igazoljuk, hogy a profilhiba mértéke és eloszlása a profileltolásoktól és a fogszámoktól függ.

Kulcsszavak: metszőkerék, fogaskerék, fogprofil, hiba, fogszám, profileltolás, eloszlás

\section{Az egyenes fogú metszőkerék éle- inek parametrikus egyenletei}

$\mathrm{Az}$ egyenes fogú metszőkerék fogának oldalfelületei, a lineárisan változó profileltolás miatt, evolvens csavarfelületek. Ezeket úgy származtatjuk, hogy az alapsíkban definiált evolvens profilt az alaphengeri csavarvonal-vezérgörbén elmozdítjuk.

Az evolvens parametrikus egyenletei, a metszőkerékhez kötött $x_{s} y_{s} z_{s}$ koordinátarendszerben a következők $[3,4]$ : 


$$
\left\{\begin{array}{l}
x_{s}(u)=R_{b}(\cos u+u \sin u) \\
y_{s}(u)=R_{b}(\sin u-u \cos u) \\
z_{s}(u)=0
\end{array}\right.
$$

Az (1) egyenletekre a $(v, p v)$ csavarmozgást alkalmazzuk. A transzformáció felírása után, a $w=u+v$ változócserével, a metszőkerék bal oldalát határoló fogfelület egyenletei a következők lesznek:

$$
\left\{\begin{array}{l}
x_{s}(u, w)=R_{b}(\cos w+u \sin w) \\
y_{s}(u, w)=R_{b}(\sin w-u \cos w) \\
z_{s}(u, w)=p(w-u)
\end{array}\right.
$$

A homlokfelület olyan egyenes körkúp, melynek tengelye a metszőkerék tengelyével egybeeső, alkotója pedig a $\gamma_{V}$ csúcshomlokszöget zárja az $x_{s} y_{s}$ síkkal. Az él torzulásának vizsgálatára a homlokfelület egyenleteibe be kell építenünk a metszőkerék újraélezési stádiumát jelző $q$ paramétert, amely a kúp csúcsának elmozdulását jelzi a $z_{s}$ tengely mentén. Ezzel a homlokfelület implicit egyenlete a következő lesz:

$$
\left(z_{s}-R_{a} \operatorname{tg} \gamma_{V}-q\right)^{2}-\left(x_{s}^{2}+y_{s}^{2}\right) \operatorname{tg}^{2} \gamma_{V}=0
$$

Az él egyenleteit az (1) és (3) összevetéséből kapott $w=w(u)$ függvény (2) egyenletrendszerbe való helyettesítése nyomán kapjuk:

$$
w(u)=\operatorname{tg} \alpha_{l b} \operatorname{tg} \gamma_{V}\left(\frac{R_{a 1}}{R_{b}}-\sqrt{1+u^{2}}\right)+u+\frac{q}{p}
$$

\section{A burkolás matematikai modellje}

A lefejtés kinematikáját, a modell egyszerüsítése végett, síkban tanulmányozzuk. Eltekintünk a cirkuláris előtolás és a fö forgácsoló mozgás időben való szuperponálásától, és ennek alapján kijelentjük, hogy a metszőkerék élei, a fö forgácsoló mozgás alatt, egy virtuális fogaskereket képeznek, amely a gyártott kerékkel kapcsolódik. Következésképpen a gyártott kerék fogprofilja a relatív mozgás során a fogazott kerék $x_{1} y_{1} z_{1}$ rendszerében létrejövő élvetületgörbék seregének burkolója [1,2,3,4].

A burkolt görbesereg egyenleteit az 1. ábra alapján vezetjük le.

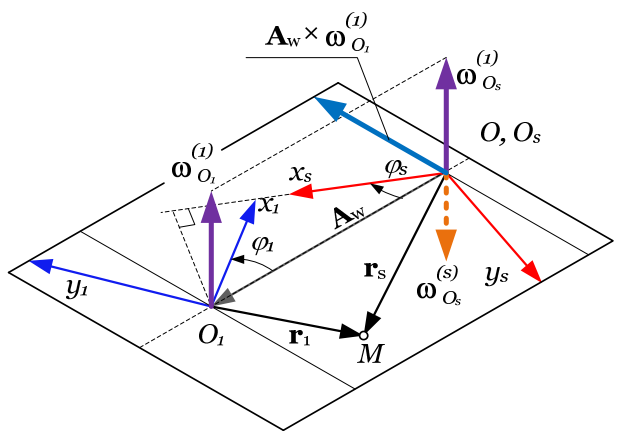

1. ábra. A koordináta-rendszerek relativ helyzete és a relativ sebesség felírásához felhasznált vektorok.

A két koordináta-rendszer közötti transzformációt az alábbi mátrixszal írjuk le:

$\mathbf{M}_{12}=\left(\begin{array}{cccc}-\cos k & -\sin k_{s} & 0 & A_{w} \cos i_{1 s} \varphi_{s} \\ \sin k_{s} & \cos k & 0 & -A_{w} \sin i_{i s} \varphi_{s} \\ 0 & 0 & 1 & 0 \\ 0 & 0 & 0 & 1\end{array}\right)$,

$k=\left(1+i_{1 s}\right) \varphi_{s}$

Figyelembe véve a $\varphi_{s}$ szerszám legördülési paramétert, illetve az $i_{1 s}=\frac{\varphi_{1}}{\varphi_{s}}=\frac{z_{s}}{z_{1}}$ fogszámarányt, a görbesereg egyenleteit a (2), (4) és (5) összefüggések alkalmazásával írjuk fel:

$$
\underline{\mathbf{r}}_{1}\left(u, w(u), \varphi_{s}\right)=\mathbf{M}_{1 s}\left(\varphi_{s}\right) \underline{\mathbf{r}}_{s}(u, w(u))
$$

A burkológörbe egyenleteit a [2]-ben ismertetett vektormódszer alapján, az 1. ábrán feltüntetett, és az $x_{1} y_{1} z_{1}$ rendszer- 
ben kifejezett vektorok segítségével számítottuk ki. A számítások homogén trigonometriai egyenlethez vezetnek, melynek elfogadható megoldása a következö:

$$
\begin{aligned}
& \varphi_{s}(u)=w(u)-E_{1}(u)-\arcsin E_{2}(u)-\pi, \\
& E_{1}(u)=\operatorname{arctg}\left(u-\frac{\sqrt{1+u^{2}}}{\operatorname{tg} \alpha_{l b} \operatorname{tg} \gamma_{V}}\right), \\
& E_{2}(u)=\frac{-R_{b}\left(1+i_{s 1}\right)}{A_{w} \sqrt{1+\operatorname{tg}^{2} \alpha_{l b} \operatorname{tg}^{2} \gamma_{V}-\frac{2 u}{\operatorname{tg} E_{1}+u}}}
\end{aligned}
$$

A burkoló profil egyenletei a (6)-ból származnak, a (7) összefüggés behelyettesítésével.

\section{A normál-profilhiba definíciója}

Normál profilhibának nevezzük a valós fogprofil (esetünkben a burkoló profil) és egy, a valós profil tetszőlegesen választott pontján áthaladó evolvens közötti, az evolvensre merőlegesen mért szakaszt. A normál profilhiba számítását a 2. ábrán szemléltetjük. Az $A M P^{\prime} Q$ evolvens a fogprofil $M$ osztóköri pontjához igazított. A profil $\rho_{y}$ sugarú körön illeszkedő $P$ pontjából az alapkörhöz húzott érintő $Q$-ban metszi az evolvenst. A $P$ pontra jellemző normál-profilhiba, értelmezés szerint, a következő:

$$
\delta_{n y}=\overline{B Q}-\overline{B P}
$$

A (8) képletet az 2. ábrán megjelölt mennyiségek segítségével kell kifejezni. A profilhiba a vizsgált profilpont polárkoordinátáitól függ. Ha a profilhiba pozitív, akkor a görbe az evolvenshez viszonyítva fogfej- illetve fogláblenyesést hajt végre, ezért, amennyiben megfelelően kicsi, elfogadható. Ha viszont a profilhiba negatív, akkor a gyártott profil helytelenül kapcsolódik.

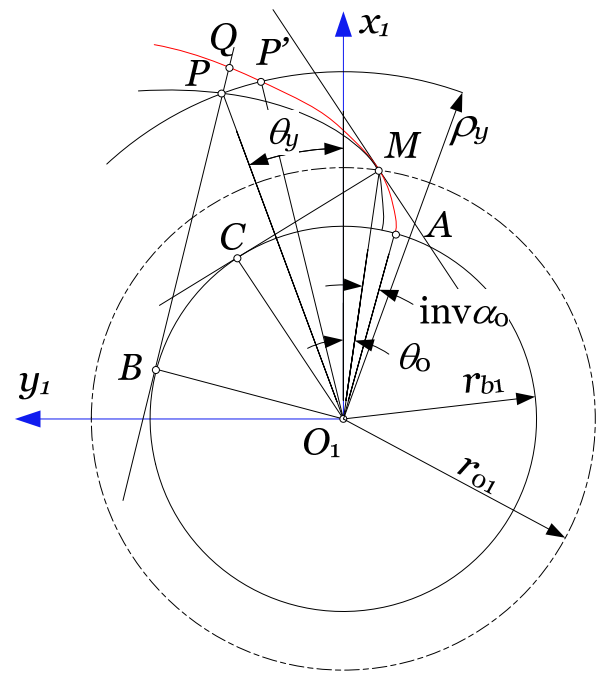

2. ábra. A normál-profilhiba definíciója

\section{A profilhiba vizsgálata}

A profilhiba változásának kimutatására $z_{s}=21$ fogú, $m=5 \mathrm{~mm}$ modulú metszőkerék hatását vizsgáltuk, ennek három élezési stádiumában, melynek rendre +0,894, $+0,492$ és $+0,091$ értékü fajlagos profileltolások felelnek meg. Ezen értékek a metszőkerék ekvivalens fogaskerekének felelnek meg [4]. A megmunkált fogaskerék fogszámát a [19, 79] intervallumban vesszük fel.

A profileltolások hatását a $z_{1}=39$ fogú kerékre vizsgáljuk. Kiszámítottuk, hogy e fogszámnak megfelelő legnagyobb profileltolás $+1,2$, a legkisebb viszont $-0,8$, a közepes érték tehát $+0,2$.

A faktorok kijelölt szintjeinek kombinációjából kilenc technológiai hajtópárt állítottunk össze, amelyre kiszámítottuk a burkoló profilt, majd pedig a normálhibát. Az eredményeket a 3., 4., illetve 5. ábrán szemléltettük. 


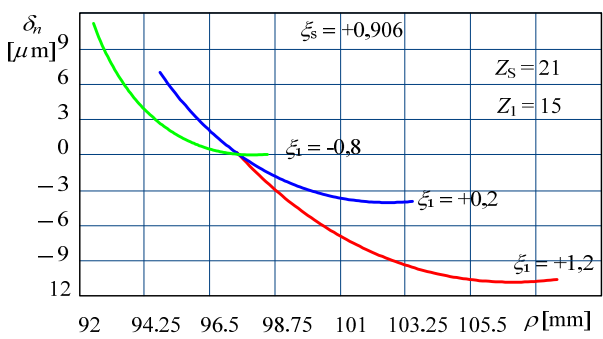

3. ábra. Új metszökerékkel generált profilhibák

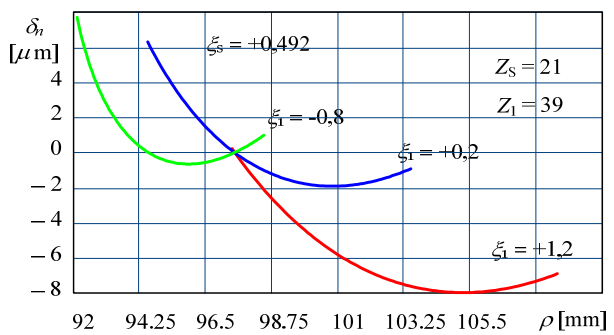

4. ábra. Félig kopott metszökerékkel generált profilhibák

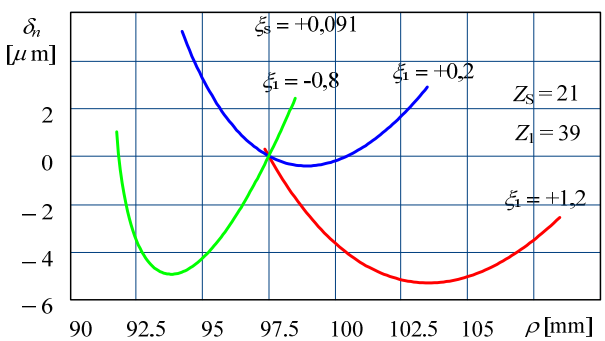

5. ábra. Kopott metszökerékkel generált profilhibák

A 3., 4. és 5. ábrák vizsgálata alapján kijelenthetjük, hogy a legnagyobb profilhiba a legnagyobb profileltolás-összegekre jelentkezik. A hibagörbék mindegyikének minimumpontja van. Ez azt jelenti, hogy ha az összehasonlító evolvenst arra a profilpontra igazítjuk, amelyben a profilhibagörbe minimumpontja van, akkor belátható, hogy az odaillesztett nullavonalhoz képest a hiba pozitív, azaz a fogfej-és fogláblenyesés megvalósul.

Észre lehet venni, hogy ennek ellenére, a fogláb- és a fogfejlenyesés mértéke annál jobban különbözik, minél nagyobb a vizsgált fogaskerék profileltolása.

Az 5. ábráról meg lehet állapítani, hogy a legideálisabb hibaeloszlás a fogaskerék közepes profileltolására, a kopott metszőkerékkel valósítható meg.

\section{Következtetések}

Bár a szakirodalom elöírja $[1,4]$, hogy a metszőkerék tervezésekor ennek lehető legnagyobb profileltolására törekedjünk, a bemutatott modellböl kiderül, hogy ez nem vezet a legjobb profil generálásához.

Bizonyos esetekben előfordul, hogy a minimumpont a használható fogmagasságon kívül található, így a hibagörbe átmetszi a nullavonalat. Ez esetben a profilgörbe egy része az evolvensen kívül illeszkedik, fej- vagy lábvastagodást okozva. Ezeket a beállításokat el kell kerülni.

A megmunkált fogaskerék fogszáma nem befolyásolja számottevő módon a profilpontosságot.

Nagy sorozatok gyártásakor megéri optimális profileltolású metszőkereket tervezni, és az utánélezések számát csökkenteni, mert ezáltal pontosabb profilt gyárthatunk.

\section{Szakirodalmi hivatkozások}

[1] Radzevich, P. S.: Dudley's Handbook of Practical Gear Design. CRC-Press, London, 2016.

[2] Litvin,F.L.: A fogaskerékkapcsolás elméle-te, Müszaki Könyvkiadó, Budapest, 1972.

[3] Hollanda, D.: Bazele așchierii și generării suprafețelor, „Petru Maior” Egyetem, Marosvásárhely, 1994.

[4] Máté, M.: Hengeres fogaskerekek gyártószerszámai, Erdélyi Múzeum-Egyesület, Kolozsvár, 2016. 